\title{
LOGISTICS CHALLENGES IN ENTERPRISE MANAGEMENT IN CONTEMPORARY CONDITIONS
}

\author{
Magdalena K. GĄSOWSKA \\ University of Warsaw, Faculty of Management; mgasowska@wz.uw.edu.pl, ORCID: 0000-0002-4971-5440
}

Purpose: The aim of the article is to analyse key logistics challenges in the enterprise management in contemporary conditions on the example of selected manufacturing and trading enterprises. On the basis of the literature studies, the author has presented contemporary trends in enterprise management and analysed key logistics challenges related to them. The research methodology has been described and the examined population has been briefly characterized. The results of the research concerning key logistics challenges in the management of the surveyed manufacturing and trading enterprises have been presented.

Design/methodology/approach: The article is based on the study of literature and own empirical research. The results of the author's empirical research presented in the article come from more extensive surveys conducted in 2017 regarding the analysis of logistics systems and logistics processes management in Polish manufacturing and trading enterprises in 2014-2016 in the context of building enterprise competitiveness. The research was conducted by the use of direct interview method with managers responsible for logistics in the surveyed companies using the author's detailed questionnaire. 298 small, medium and large enterprises were examined from Warmia-Masuria Province (55.4\%) and Podlasie Province (44.6\%), characterized by a diversified competitive position on the market.

Findings: The conducted research confirmed that meeting the contemporary challenges of enterprise management depends more and more on logistics. Logistics activities and logistics solutions enabled the surveyed companies to create competitive advantage, increase profit, profitability and enterprise value, and build competitiveness. Logistics managers from the best surveyed companies combined a strategic approach for creating a comprehensive concept of logistics activities and solutions with a quick and adequate response to permanently changing market conditions. Due to the limited volume of the article, only selected aspects of key logistics challenges in the management of the surveyed enterprises were presented.

Research limitations/implications: The literature emphasizes that logistics will have an ever growing influence on enterprise management, which is also confirmed by the empirical studies; more and more logistics managers, including in Polish companies, administer logistics processes on the scale of an enterprise and the entire supply chain, or on the scale of an enterprise including opportunities and threats resulting from the existence of a network of co-operators and opportunities associated with establishing relationships with new co-operators. The issues presented in the article require further, in-depth research.

Practical implications: The results of theoretical and empirical studies presented in the article have a practical significance. The author offered logistics managers of Polish manufacturing and trading enterprises practical suggestions for using logistics in the process of enterprise management and presented key challenges related to them. 
Originality/value: The article fills the cognitive gap regarding the issues of key logistics challenges in enterprise management in contemporary conditions. The author carried out a comprehensive literature review on contemporary trends in the enterprise management and analysis of key logistics challenges related to them. The article also fills the empirical gap. It presents the research results concerning key logistics challenges in management of the surveyed manufacturing and trading enterprises. The research results presented in the article can be used by logistics managers of Polish manufacturing and trading enterprises.

Keywords: enterprise, changes in enterprises management, enterprise competitiveness, logistics, logistics challenges.

Category of the paper: Research paper.

\section{Introduction}

An increasing rate of changes, economic globalization, complexity, uncertainty, growing and changing requirements and expectations of customers, low cost pressure, low prices, increasing interest of governments and societies in the concept of sustainable development, rapid technological progress, sharpening competitive struggle, and consequently, volatility and impermanence of competitive advantages and high risk determine the functioning of contemporary business entities (Taleb, 2007; Taleb, et al., 2009; Kahneman, 2011; Kahneman, et al., 2011; McGrath, 2013; Stańczyk-Hugiet, 2013; Krzakiewicz, and Cyfert, 2014; Nogalski, and Szpitter, 2014; Teece, et al., 2016; Romanowska, 2016; Bendkowski, 2017; Buła, and Żak, 2017; Christopher, and Holweg, 2017; Paprocki, 2017; Jasiński, et al., 2019; Mishra, et al., 2019). Changes in various conditions of management occur simultaneously, overlap, create a combination of explicit and implicit states, to a large extent unpredictable, and constitute a great challenge in terms of changes in the methods of enterprise management.

A quick, adequate and effective response of enterprises to challenges related to the contemporary conditions of management increasingly depends on a proper management of logistics processes that concern the physical flows (raw materials, materials, production in progress, finished products and goods) and information related to them in the enterprise and between the business entities involved in delivering a product to a customer. Logistics is responsible for managing logistics processes in order to provide the customers the most desirable service at the lowest possible costs. Logistics processes of business entities are implemented as a part of a logistics system, which is defined as a purposefully organized and integrated flow of materials and products through subsequent configurations of nodes and paths within a given economic system (Kisperska-Moron, and Sołtysik, 1996). The logistics system of an enterprise should constitute a response to key challenges of contemporary logistics, create a unique value for a client in comparison with competitors, and provide a higher added value for the enterprise than the competitors. The aim of the article is to analyse key logistics 
challenges in enterprise management in contemporary conditions on the example of selected manufacturing and trading companies.

\section{Contemporary trends in enterprise management and key logistics challenges}

In the process of enterprise management, contemporary managers must take into account dynamically changing conditions and expectations of various groups of stakeholders. In such conditions, enterprises must create the ability to adapt, i.e. the ability to adapt to the operation conditions which involves the necessity to make changes (Osbert-Pociecha, 2011a). At the same time, enterprises must build and improve dynamic capabilities (Wilhelm, et al., 2015; Penc-Pietrzak, 2015; Fainshmidt, et al., 2016). The basic component of dynamic capabilities of an enterprise is its ability to change, i.e. to respond to specific impulses from its environment or interior (Osbert-Pociecha, 2011b). An enterprise with dynamic capabilities has certain predispositions, including the appropriate configuration of resources, structures and methods of operation that allow it to efficiently design and implement the whole bundle of changes. Logistics managers should provide the enterprise with the possession and usage of logistics resources, their development and renewal, which is possible thanks to organizational learning processes (Krupski, 2012). One of the most important challenges of logistics managers is determining the essence of changes in the area of the logistics system, their scope, direction, links to changes already made and changes planned in the long-term as well as implementing a whole set of changes concerning the logistics system.

Only competitive entities of the market can handle the global, sharpening competition. The key task of enterprise management is to provide the enterprise with an appropriate level of competitiveness (Stankiewicz, 2011, p. 147). The views of scientists on competitiveness are subject to systematic transformations along with the changing market conditions and development of economic sciences. According to the author of this study, the competitiveness of an enterprise is its ability to strengthen and improve its market position, achieving, at the same time, a higher level of efficiency than its competitors and permanently shaping and effectively maintaining its growth (Gąsowska, 2018, p. 34). The article assumes that the effectiveness of an enterprise indicates the ratio of the effects achieved by the enterprise to the incurred expenditures. Building competitiveness of an enterprise requires the usage of a strategic approach to create logistics activities and solutions which are implemented at the strategic and operational level in the enterprise. The key challenge of logistics managers is adjustment of logistics processes to wishes and expectations of customers and gaining, proper configuration and effective usage of resources, which are adequate to the changing conditions, 
valuable and difficult to copy, in order to ensure the desired increase in profitability and enterprise value while respecting the principles of sustainable development.

In the conditions of volatility and impermanence of competitive advantages, the key challenge for managers is a fast identification of new sources of competitive advantage, making adequate reconfiguration of resources, maximizing the usage of these sources and moving to the usage of other possibilities of achieving competitive advantage before competitors. The desired attribute of contemporary enterprises is flexibility that constitutes the ability of the system to respond in a short time to changes in external conditions and internal changes in the configuration of own potentials (Grajewski, 2012). Long-term corporate strategies are being replaced by emergent strategies, i.e. those which are in a constant stage of creation, shaping, which are flexible and characterized by a rapid response to changing requirements of customers, environmental conditions and activities of competitors (Stańczyk-Hugiet, 2013; Płoszajski, 2014). Contemporary logistics managers should create logistics systems that have a high level of flexibility. Systems characterized by a high level of flexibility allow enterprises to renew competitive advantages, maintain an advantage over their competitors and effective defence against copying skills.

The rapid pace of changes and increase in their complexity made the process orientation one of the basic contemporary orientations in management. In the process approach, the enterprise constitutes a set of mutually penetrating processes. Process management is based on the constant striving to optimize organizational elements from the point of view of their influence on creating added value, which translates into a faster adaptation to the changing conditions, implementation of innovations, achieving a higher level of customer satisfaction, an increase in efficiency and competitiveness (Harmon, 2010; Bititci, et al., 2011). Contemporary managers implementing the process orientation in their enterprises should have dynamic and comprehensive influence on the processes taking place in the organization in accordance with strategic assumptions in order to build value for a client and other stakeholders (Bitkowska, 2019).

Shaping logistics processes in the existing market conditions requires a creative and integrated approach that takes into account connections of all organizations that are suppliers and recipients to each other and dynamics of changes in the business conditions. Involvement of employees and logistics managers with appropriate skills and competencies is a prerequisite for building enterprise competitiveness. Logistics processes of contemporary enterprises should be system-oriented in the global supply network to satisfy requirements and expectations of customers at the lowest possible costs with the full information availability about the assumptions, course and effects of processes and the full consideration of requirements and expectations of the environment (Jedliński, 2015). In the present economic reality, enterprises achieve better results by competing with supply chains or participating in a supply network. 
Enterprises competing with a supply chain synchronize physical, informational and financial streams of demand and supply flowing between enterprises being its links in order to create added value and achieve sustainable competitive advantage. In creating, implementing and transforming logistics processes of enterprises which create the supply chain dominates the philosophy of close integration of organizations being links of that chain; relationships are built on the principles of trust and risk-benefit sharing (Witkowski, 2010; Szymczak, 2015; Stevens, and Johnson, 2016). Current trends in the evolution of supply chains aim at: flexibility of operation, sensitivity to the needs of a recipient and resilience to disruptions (Szymczak, 2015).

Supply chains include a group of independent, competing and cooperating companies in order to improve the efficiency and effectiveness of the flow of products and information associated with it in accordance with the expectations of the customers, between whom there is no clear relationship of subordination, operating on the principles of exchange and mutual trust for the implementation of common goals. Competitive advantage can be achieved by enterprises in which managers run the enterprise taking into account opportunities and threats resulting from the existence of a network of co-operators and opportunities associated with establishing relationships with new co-operators (Mitręga, 2010). Networks are very slightly susceptible to imitation, transfer or substitution. An enterprise that is able to gain competitive advantage thanks to its participation in the network, because of the network context, keeps it in the long term (Czakon, 2012).

In conditions of increasing volatility, complexity and unpredictability, only organizations that learn quickly and create organizational knowledge can endure and compete effectively (Malara, and Rzęchowski, 2011). Cooperation of the enterprise with entities participating in delivery of a product to a client enables the mutual creation and acquisition of logistics knowledge and its fast use in activities aimed at adapting to the market conditions and creating and maintaining its competitive advantage.

The best enterprises build their competitive positions using modern technologies. The usage of modern information technologies is of fundamental importance in the process of configuration and management of the chain or supply network (Długosz, 2012). The key challenge of contemporary logistics managers is to build an information system that enables the integration of logistics processes; this creates an attitude to solve logistics problems enabling a quick response to threats, appropriate usage of opportunities and reduction of uncertainty and risk associated with activities and logistics solutions on the scale of the enterprise and the entire market system.

Enterprises and supply chains can implement logistics processes based on their own logistics resources, logistics capabilities and logistics competencies or outsource the organization and/or implementation of all or part of logistics processes to specialized logistics service providers. Contemporary enterprises should use the engagement model of outsourcing assuming a longer-term contract in which effective outsourcing is based on the optimization of three key objectives: innovation and a higher level of services, cost reduction in a company 
using outsourcing and increased profits for the supplier (Vitasek, 2016). One of the most important challenges of logistics managers is the proper selection and usage of key competencies of logistics service providers in order to achieve the increase in the efficiency of the enterprise's logistics processes, stimulate the development of its key competencies and, as a consequence, offer customers greater value and create competitive advantage of the enterprise.

Innovations are currently the most important sources enabling enterprises to achieve competitive advantage (Gąsowska, 2014; Nowicka-Skowron, et al., 2017). In order to react quickly to permanent market changes and build enterprise competitiveness, logistics managers should create and implement non-standard logistics processes, which meet the requirements of customers at the lowest possible cost but also meet the goals of the enterprise. The process of creating and implementing reactive innovations should be short and flexible. Managers should permanently identify emerging threats, cost reduction opportunities, emerging opportunities and implement appropriate adaptation processes to changing market conditions. On the other hand, the implementation of proactive innovations requires the effective inclusion of clients and enterprises participating in the process of delivering a product to clients to cooperate on an innovative solution. Absorption and skilful application of knowledge from outside of the enterprise become key factors ensuring the organization the long-term growth in innovation, continuous learning and maintaining or increasing its competitive advantage (Anussornnitisarn, et al., 2010; Seo, et al., 2014; da Mota Pedrosa, et al., 2015). The key challenge for logistics managers is the implementation of logistics innovations that create uniqueness ensuring an increase in sales and profit growth.

Contemporary enterprises should adopt a total risk and uncertainty orientation (Urbanowska-Sojkin, 2013, p. 39). Managers should undertake activities that protect the enterprise against certain types of risk, but also should take some risks skilfully (Damodaran, 2009). Enterprises must be more dynamic, intelligent, equipped with information and other resources more than ever before to be able to reduce and mitigate risk. Systemic risk management has become a strategic task for business managers (Urbanowska-Sojkin, 2013). An effective risk management system should not limit innovations and implement risky ventures (Kaplan, and Mikes, 2016). Economic entities should analyse risk, reduce it and protect themselves against it in a cost-effective manner. The key challenge for contemporary logistics managers is systemic risk management. Logistics managers should prevent crises in the enterprise by early detection of threats in the environment and development of resilience to a crisis, and prepare the enterprise to act in a crisis if it cannot be avoided (Romanowska, 2016). Those particularly vulnerable to disruptions are multi-organization, complex, global supply chains. The key attributes of disruption-resilient supply chains are flexibility and adaptability (Kramarz, M., and Kramarz, W., 2014). 
The increasing interest of governments and societies in the concept of sustainable development, pressure of organizations supervising the activities of enterprises, clients and investors cause that more and more enterprises are implementing the concept of corporate social responsibility. The implementation of the concept of corporate social responsibility in the enterprise logistics and supply chain is increasingly perceived as a key factor in achieving desired results, risk reduction and building competitiveness (Urbaniak, 2014; Ortas, et al., 2014; Buła, and Żak, 2017). The implementation of the concept of corporate social responsibility presents the logistics managers with great challenges (Gąsowska, 2016). Logistics managers should analyse, diagnose and monitor the impact of logistics processes and technologies on the society and environment and create, implement and transform logistics processes in such a way as to reconcile contradictory requirements set for the enterprise by customers, owners, co-operators, suppliers, employees, communities and other stakeholders.

\section{Research methodology}

The results of author's empirical research presented in the article come from more extensive surveys conducted in 2017 regarding the analysis of logistics systems and logistics processes management in Polish manufacturing and trading enterprises in 2014-2016 in the context of building enterprise competitiveness (Gąsowska, 2018). The research was conducted by the use of the direct interview method with managers responsible for logistics in the surveyed companies using the author's detailed questionnaire. 298 small, medium and large enterprises were examined from Warmia-Masuria Province (55.4\%) and Podlasie Province (44.6\%), characterized by a diversified competitive position on the market.

The largest group of the surveyed enterprises was made up of small enterprises $(45.7 \%)$. Medium enterprises in the surveyed population constituted $31.5 \%$. The smallest group of the surveyed enterprises were large enterprises $(22.8 \%)$. The manufacturing and trading enterprises taking part in the surveyed population constituted a similar number. The manufacturing enterprises constituted $50.3 \%$ of the surveyed companies $(19.5 \%$ small manufacturing enterprises, $17.7 \%$ medium manufacturing enterprises, $13.1 \%$ large manufacturing enterprises), while trading enterprises constituted $49.7 \%$ of the surveyed population $(26.2 \%$ small trading enterprises, $13.8 \%$ medium trading enterprises, 9.7\% large trading enterprises).

The analysis of the surveyed enterprises according to the sales revenue criterion allowed to conclude that the largest group among them were companies achieving in 2016 revenues from sales up to PLN 10 million (43.3\%). The second largest surveyed group were enterprises achieving revenues from sales between PLN 10-50 million (30.5\%). Companies achieving revenues from sales between PLN 50-100 million constituted 10.1\% of the surveyed 
population. The smallest group of the surveyed population were enterprises which in 2016 achieved revenues from sales between PLN 500-1000 million.

\section{Key logistics challenges in management of the surveyed enterprises - selected aspects}

Basic goals of an enterprise orientate its activity, constitute the basis for formulating the strategy of enterprise management, determine the entire enterprise management system and are the reference point for the assessment of activities and controls. The respondents of this study were asked to indicate the basic goals that were implemented in their enterprises in 2014-2016. The goals most often indicated by the participants of the research were: maximization of the market value of the enterprise $(53.4 \%$ in $2014,57.1 \%$ in $2015,59.5 \%$ in 2016), profit maximization $(53.0 \%$ in $2014,57.4 \%$ in $2015,58.4 \%$ in 2016$)$ and sales maximization $(48.3 \%$ in $2014,47.7 \%$ in $2015,49.0 \%$ in 2016). As has already been emphasized, a more and more important challenge for contemporary enterprises is to respect the principles of sustainable development. Enterprises in which the basic objective was to balance economic, social and environmental goals constituted a small group of the surveyed population $(14.1 \%$ in 2014 , $17.1 \%$ in $2015,17.7 \%$ in 2016). The vast majority of the respondents indicated more than one enterprise's primary goal. The examined companies primarily aimed at achieving related goals. A few enterprises striving to meet the expectations of various groups of stakeholders implemented divergent goals (e.g. maximizing profit and balancing economic, social and environmental goals), which confirms the existence of contradictions in the management of contemporary companies. Enterprise competitiveness is a prerequisite for implementation of the vast majority of the core objectives of the examined companies.

Logistics goals orientate the logistics activities of the enterprise, establish their scope, determine the logistics system and logistics process management and constitute the reference point of the logistics assessment. The respondents of this study were asked to indicate the enterprise's logistics goals in 2014-2016. All examined enterprises had clearly defined logistics goals in the analysed period. In most companies the logistics objectives were: improvement of customer service $(64.1 \%$ in $2014,67.4 \%$ in $2015,69.1 \%$ in 2016$)$, reduction of logistics costs (52.3\% in $2014,54.7 \%$ in $2015,57.1 \%$ in 2016$)$ and shaping competitive advantage of the enterprise $(52.0 \%$ in $2014,55.0 \%$ in $2015,58.4 \%$ in 2016$)$.

As a result of the research, it has been found that the basic objectives, mission, strategic market and financial goals and logistics goals determined the logistics system and logistics process management in the vast majority of the enterprises. The vast majority of the surveyed enterprises had defined logistics goals in their operational plans $(75.5 \%$ in $2014,77.2$ in 2015 , $77.5 \%$ in 2016). Most of the surveyed enterprises tried to adequately respond to the changing 
market conditions and seize and take advantage of emerging opportunities without identifying ways to achieve designated logistics goals in the formal framework of strategic plans. On the other hand, a large and most growing group in the analysed period was made up of enterprises incorporating logistics goals into the strategic planning process $(37.2 \%$ in 2014 , $40.3 \%$ in $2015,43.4 \%$ in 2016 ), which ensured them a systematic, consistent pursuit of achieving their goals. In the majority of the examined medium and large enterprises, the methods of implementing logistics goals were defined in their strategic plans.

Constraints in the process of building enterprise competitiveness in 2014-2016 constituted the subject of the research. The analysis of the research results allowed to draw the conclusion that in the majority of the companies the main constraints in the process of building the competitiveness were the unfavourable market conditions (73.2\%) and insufficient competitiveness potential (52.7\%). Subsequently, the respondents mentioned the following limitations in the process of building the enterprise competitiveness in the analysed period: high costs of running business (47.3\%), lack of qualified employees (40.9\%), inability to quickly respond to emerging opportunities $(34.3 \%)$, problems with maintaining the financial liquidity $(31.9 \%)$, lack of mutual trust and openness to information exchange with business partners $(30.5 \%)$.

The respondents were asked to indicate the elements of the logistics potential of the enterprise competitiveness that should be developed to increase enterprise's ability to strengthen and improve its competitive position in 2014-2016. The participants of the study most often indicated that building competitiveness in the analysed period required developing logistics resources, logistics capabilities and logistics competencies, which resulted in a low level of logistics costs $(46.0 \%)$, the logistics system of the enterprise (43.3\%) and logistics resources, logistics capabilities and logistics competencies, which resulted in the required and expected level of customer service (40.9\%). The elements of the logistics potential of the competitiveness that, according to many respondents, should be developed in order to build enterprise competitiveness were: skills and competencies of logistics employees $(36.2 \%)$, innovations (34.2\%), procurement logistics (33.0\%) and logistics information system $(31.9 \%)$.

The research examined the degree of cooperation between the surveyed enterprises with entities in the supply chain in the area of logistics activities and solutions in 2014-2016. The analysis of the research results gave the basis for the conclusion that the surveyed enterprises did not integrate logistics processes with all entities being links of the supply chain; the vast majority of the companies did not build relationships in the supply chain based on the principles of trust and risk-benefit sharing, which translated into ineffective use of additional possibilities that would improve the level of customer service, reduce costs, increase operational efficiency and flexibility and reduce risk.

The risk associated with the implementation of logistics processes in the surveyed enterprises in the years 2014-2016 was also the subject of the analysis. The majority of the respondents indicated the following risk factors associated with the implementation of logistics 
processes in the analysed period: growing competition, dynamic changes, fluctuations in prices of raw materials, products and basic services and human errors. The analysis of the results of the conducted research led to the conclusion that the respondents are aware of the increasing risk associated with the implementation of logistics processes, more and more research participants notice a significant influence of logistics on the enterprise resilience to disruptions and reduction of operational risk, however, only about $10 \%$ of the surveyed companies implemented systemic risk management in the analysed period. Building enterprise competitiveness in the current conditions requires systemic risk management in the logistics processes. Logistics activities and logistics solutions should be used in enterprises to foresee disruptions in the company's environment and its interior, reduce operational risk and adequately respond to the effects of the disruptions.

The research also included the actual changes in logistics activities and solutions inside an enterprise and between enterprises in 2014-2016. Most respondents indicated that the change in logistics activities and solutions in the analysed period was the improvement of the customer service $(51.3 \%$ in $2014,55.7 \%$ in $2015,58.1 \%$ in 2016$)$ and the increase in the ability to achieve a competitive advantage (42.6\% in $2014,47.3 \%$ in $2015,54.0 \%$ in 2016 ). The results of the conducted research gave the basis for the conclusion that the changes made in the logistics activities and solutions of the surveyed enterprises enabled them to better adapt to the changing operating conditions. As a result of the changing market conditions, the surveyed enterprises tightened cooperation with suppliers and customers, implemented new logistics technologies, reduced the level of maintained stocks, developed reliability of deliveries, increased sensitivity to the market requirements, outsourced logistics processes, cooperated in a network, balanced the supply chain, made changes in the logistics personnel management. Not all logistics goals were achieved by the surveyed enterprises. The majority of the surveyed enterprises improved their customer service, increased their ability to achieve competitive advantage, reduced logistics costs, increased flexibility and efficiency of the logistics information system. On the other hand, some of the enterprises did not achieve these effects although these were the logistics goals in the analysed period and the lack of the implementation of these objectives adversely affected building competitiveness of these companies.

As a result of the research, it has been found that the vast majority of the surveyed companies (80.9\%) implemented logistics innovations in the analysed period. The implemented logistics innovations in most of the companies were not a consequence of the planned activities, they were forced by the changing market conditions, thus the economic account played a key role in decisions on their implementation. The implemented logistics innovations primarily contributed to the improvement of the customer service, work organization, achievement of reliability advantage, cost advantage, flexibility advantage and reduction of capital involvement, which translated into an increase in sales and profit growth. Almost every third surveyed manufacturing enterprise has also implemented logistics innovations in the production area. The cooperation of the examined companies with clients and suppliers in the process of 
creating and implementing logistics innovations contributed to the increase in the enterprise's ability to strengthen and improve its market position.

The logistics strategies used in practice of the surveyed enterprises in 2014-2016 were also examined. The vast majority of the surveyed enterprises had developed a coherent concept of systemic operation in the area of logistics whose implementation was aimed at achieving a competitive advantage. The most frequently implemented logistics strategy in the surveyed competitive enterprises was the strategy of supply chain management. The emergent logistics strategy was implemented in the majority of competitive companies, which was in a constant stage of creating and shaping and characterized by a quick response to the changing requirements of customers, environmental conditions and activities of competitors.

The research shows that the operational management of logistics processes also had a significant influence on the economic and market performance of the best companies. These enterprises created, transformed, coordinated and integrated logistics processes inside the enterprise and between entities being links in the supply chain in order to quickly and adequately respond to the requirements and expectations of customers, changing conditions and activities of competitors at the lowest costs, to take advantage of emerging opportunities, mitigate the negative influence of unfavourable conditions on profitability and financial liquidity, implement logistics innovations, and consequently, increase sales revenues, reduce logistics costs, increase flexibility and resource productivity, which translated into permanent shaping and effective maintaining of the highest possible increase in operational efficiency. The best surveyed companies combined a strategic approach to creating a comprehensive concept of logistics activities and solutions with a quick and adequate response to permanently changing market conditions.

\section{Conclusion}

Dynamically changing, more and more complex and to a large extent unpredictable conditions of functioning of contemporary business entities pose a great challenge in terms of changes in the methods of enterprise management. Managers are forced to look for ways to quickly, adequately and effectively respond to the current conditions and create a long-term advantage over competitors being the consequence of creating and implementing short-term competitive advantages that will ensure the achievement of the expected market and economic effects. The conducted research confirmed that meeting the contemporary challenges of enterprise management depends more and more on logistics. Logistics activities and logistics solutions enabled the surveyed companies to create competitive advantage, increase profit, profitability, enterprise value and build competitiveness. Logistics managers from the best surveyed companies combined a strategic approach to creating a comprehensive concept of 
logistics activities and solutions with a quick and adequate response to permanently changing market conditions.

The research confirmed that the key challenges of contemporary logistics managers include: integration of logistics problems into the strategic planning process; acquisition, proper configuration and effective usage of logistics resources, logistics capabilities and logistics competences, adequate to changing conditions, valuable, rare and difficult to copy; creation of global supply chains, global supply networks; quick and adequate response to the requirements and expectations of customers, changing conditions and activities of competitors at the lowest possible costs; usage of emerging opportunities; mitigating the negative influence of unfavourable conditions on profitability and financial liquidity; usage of modern technologies to create, implement and transform logistics processes; systemic activities leading to the identification and reduction of uncertainty and risk of the conducted activity; achieving the greatest possible flexibility of operation; sensitivity to the needs of a recipient; resilience to disruptions; building partner relations with suppliers, whose effect is the mutual implementation of product, process and organizational innovations that contribute to the improvement of efficiency and effectiveness of logistics processes; development of employee competencies; creation of new logistics knowledge, its dissemination among companies cooperating with the enterprise and its usage to create new products, technologies and organizational solutions; usage of advanced and precise systems for measuring logistics effects and balancing economic, ecological and social goals. Due to the limited volume of the article, only selected aspects of key logistics challenges in the management of the surveyed enterprises were presented.

\section{References}

1. Anussornnitisarn, P., Sanpanisch, S., Phusavat, K., Kess, P., Muhos, M. (2010). Sustaining organizational innovation and learning through external knowledge. International Journal of Innovation and Learning, 7(1), 85-99.

2. Bendkowski, J. (2017). Zmiany w pracy produkcyjnej w perspektywie koncepcji „Przemysł 4.0”. Zeszyty Naukowe Politechniki Śląskiej. Seria Organizacja i Zarządzanie, (112), 21-33.

3. Bititci, U.S., Ackermann, F., Ates, A., Davies, J., Garengo, P., Gibb, S., MacBryde, J., Mackay, D., Maguire, C., van der Meer, R., Shafti, F., Bourne, M., Firat, S.U. (2011). Managerial processes: business process that sustain performance, International Journal of Operations \& Production Management, 31(8), 851-891. https://doi.org/10.1108/ 01443571111153076. 
4. Bitkowska, A. (2019). Od klasycznego do zintegrowanego zarzadzania procesowego. Warszawa: C.H. Beck.

5. Buła, P., Żak, A. (2017). Dyfuzja wspólnych działań w kierunku idei społecznej odpowiedzialności biznesu - CSR 3.0+. In: A. Sopińska, P. Wachowiak (Eds.), Wyzwania współczesnego zarządzania strategicznego (pp. 405-425). Warszawa: Oficyna Wydawnicza SGH.

6. Christopher, M., Holweg, M. (2017). Supply chain 2.0 revisited: a framework for managing volatility-induced risk in the supply chain. International Journal of Physical Distribution \& Logistics Management, 47(1), 2-17. https://doi.org/10.1108/IJPDLM-09-2016-0245.

7. Czakon, W. (2012). Sieci w zarządzaniu strategicznym. Warszawa: Wolters Kluwer business.

8. Damodaran, A. (2009). Ryzyko strategiczne. Podstawy zarządzania ryzykiem. Warszawa: Wydawnictwa Akademickie i Profesjonalne.

9. da Mota Pedrosa, A., Blazevic, V., Jasmand, C. (2015). Logistics innovation development: a micro-level perspective. International Journal of Physical Distribution \& Logistics Management, 45(4), 313-332. https://doi.org/10.1108/IJPDLM-12-2014-0289.

10. Długosz, J. (2012). Przedsiębiorstwo przyszłości uwarunkowane rozwojem technologii informacyjnych. In: W. Wieczerzycki (Eds.), E-logistyka@ (pp. 241-251). Warszawa: PWE.

11. Fainshmidt, S., Pezeshkan, A., Frazier, M.L., Nair, A., Markowski, E. (2016). Dynamic capabilities and organizational performance: a meta-analytic evaluation and extension. Journal of Management Studies, 53(8), 1348-1380. https://doi.org/10.1111/joms.12213.

12. Gąsowska, M.K. (2018). Logistyka a konkurencyjność przedsiębiorstwa. Warszawa: Difin.

13. Gąsowska, M.K. (2016). Menedżerowie logistyki wobec wyzwań społecznej odpowiedzialności biznesu. Przedsiębiorczość i Zarządzanie, 17(12, 2), 91-104.

14. Gąsowska, M.K. (2014). Rola innowacji w procesie zarządzania przedsiębiorstwem w warunkach wahań koniunktury na przykładzie wybranych przedsiębiorstw. Zeszyty Naukowe Politechniki Śląskiej. Seria: Organizacja i Zarządzanie, 74, 513-524.

15. Grajewski, P. (2012). Procesowe zarzadzanie organizacją. Warszawa: PWE.

16. Harmon, P. (2010). The scope and evolution of business process management. In: J. vom Brocke, M. Rosemann (Eds.), Handbook on Business Process Management. Part 1 (pp. 37-81). Berlin-Heidelberg: Springer.

17. Jasiński, A.H., Głodek, P., Jurczyk-Bunkowska, M. (2019). Organizacja i zarzadzanie procesami innowacyjnymi. Warszawa: PWE.

18. Jedliński, M. (2015). Logistyczna optyka w biznesie - panaceum pewności wobec ekonomii niepewności? Prace Naukowe Uniwersytetu Ekonomicznego we Wrocławiu, 382, 41-52.

19. Kahneman, D., Lovallo, D., Sibony, O. (2011). Before you make that big decision... Harvard Business Review, 89(6), 51-60.

20. Kahneman, D. (2011). Thinking, fast and slow. New York: Farrar, Straus and Giroux. 
21. Kaplan, R.S., Mikes, A. (2016). Risk management - the revealing hand. Journal of Applied Corporate Finance, 28(1), 8-18. https://doi.org/10.1111/jacf.12155.

22. Kisperska-Moroń, D., Sołtysik, M. (1996). System logistyczny przedsiębiorstwa. Katowice: Wydawnictwo Akademii Ekonomicznej.

23. Kramarz, M., Kramarz, W. (2014). Elastyczność i adaptacyjność w budowaniu odpornych łańcuchów dostaw. In: A. Sopińska, S. Gregorczyk (Eds.), Granice strukturalnej złożoności organizacji (pp. 173-184). Warszawa: Oficyna Wydawnicza SGH.

24. Krupski, R. (2012). Rozwój szkoły zasobów zarządzania strategicznego. Przegląd Organizacji, 4, 3-7.

25. Krzakiewicz, K., Cyfert, S. (2014). The concept of management by flexible goals. Management, 18(1), 124-135. doi:10.2478/manment-2014-0010.

26. Malara, Z., Rzęchowski, J. (2011). Zarządzanie informacja na rynku globalnym. Teoria i praktyka. Warszawa: C.H. Beck.

27. McGrath, R.G. (2013). Continuous reconfiguration in the transient advantage economy. Strategy \& Leadership, 41(5), 17-22. https://doi.org/10.1108/SL-05-2013-0039.

28. Mishra, B.K., Rolland E., Satpathy, A., Moore, M. (2019). A framework for enterprise risk identification and management: the resource-based view. Managerial Auditing Journal, 34(2), 162-188. https://doi.org/10.1108/MAJ-12-2017-1751.

29. Mitręga, M. (2010). Zdolność sieciowa jako czynnik przewagi konkurencyjnej na rynku przedsiębiorstw. Katowice: Wydawnictwo Akademii Ekonomicznej.

30. Nogalski, B., Szpitter, A. (2014). Koncepcja sustainability jako determinanta rozwoju przedsiębiorstwa. In: I. Hejduk, A. Herman (Eds.), Dla przyszłości (pp. 197-210). Warszawa: Difin.

31. Nowicka-Skowron, M., Krawczyk-Sokołowska, I., Mesjasz-Lech, A. (2017). Strategie innowacji w warunkach konkurencyjności. In: A. Sopińska, P. Wachowiak (Eds.), Wyzwania współczesnego zarządzania strategicznego (pp. 257-273). Warszawa: Oficyna Wydawnicza SGH.

32. Ortas, E., Moneva, J.M., Álvarez, I. (2014). Sustainable supply chain and company performance: A global examination. Supply Chain Management: An International Journal, 19(3), 332-350. https://doi.org/10.1108/SCM-12-2013-0444.

33. Osbert-Pociecha, G. (2011a). Zdolność do zmian jako siła sprawcza elastyczności organizacji. Wrocław: Wydawnictwo Uniwersytetu Ekonomicznego.

34. Osbert-Pociecha, G. (2011b). Ewolucja paradygmatów zarządzania a zarządzanie zmianami. In: Z. Dworzecki, B. Nogalski (Eds.), Przełomy w zarzadzaniu. Kontekst strategiczny (pp. 137-157). Toruń: TNOiK Dom Organizatora.

35. Paprocki, W. (2017). Digital economy as an environment for virtual platform operators. Journal of Management and Financial Sciences, X(30), 11-26. 
36. Penc-Pietrzak, I. (2015). Charakterystyka zdolności dynamicznych w warunkach hiperkonkurencji. Studia Ekonomiczne. Zeszyty Naukowe Uniwersytetu Ekonomicznego w Katowicach, 229, 143-156.

37. Płoszajski, P. (2014). Współczesne otoczenie organizacji. In: M. Strużycki (Eds.), Podstawy zarzadzania (pp. 67-84). Warszawa: Oficyna Wydawnicza SGH.

38. Romanowska, M. (2016). Kryzys w przedsiębiorstwie. In: M. Romanowska, W. Mierzejewska (Eds.), Przedsiębiorstwo odporne na kryzys (pp. 15-34). Warszawa: Oficyna a Wolters Kluwer business.

39. Seo, Y.J., Dinwoodie, J., Kwak, D.W. (2014). The impact of innovativeness on supply chain performance: is supply chain integration a missing link?. Supply Chain Management: An International Journal, 19(5/6), 733-746. https://doi.org/10.1108/SCM-02-2014-0058.

40. Stankiewicz, M.J. (2011). Konkurencyjność przedsiębiorstwa. In: B. Godziszewski, M. Haffer, M.J. Stankiewicz, S. Sudoł (Eds.), Przedsiębiorstwo. Teoria i praktyka zarzadzania (pp. 147-177). Warszawa: PWE.

41. Stańczyk-Hugiet, E.I. (2013). Dynamika strategiczna w ujęciu ewolucyjnym. Wrocław: Wydawnictwo Uniwersytetu Ekonomicznego.

42. Stevens, G.C., Johnson, M. (2016). Integrating the Supply Chain ... 25 years on. International Journal of Physical Distribution \& Logistics Management, 46(1), 19-42. https://doi.org/10.1108/IJPDLM-07-2015-0175.

43. Szymczak, M. (2015). Ewolucja łańcuchów dostaw. Poznań: Wydawnictwo Uniwersytetu Ekonomicznego.

44. Taleb, N.N., Goldstein, D.G., Spitznagel, M.W. (2009). The six mistakes executives make in risk management. Harvard Business Review, 87(10), 78-81.

45. Taleb, N.N. (2007). The black swan: the impact of the highly improbable. New York: Random House.

46. Teece, D., Peteraf, M., Leih, S. (2016). Dynamic capabilities and organizational agility: risk, uncertainty, and strategy in the innovation economy. California Management Review, 58(4), 13-35. https://doi.org/10.1525/cmr.2016.58.4.13.

47. Urbaniak, M. (2014). Wpływ znormalizowanych systemów zarządzania oraz narzędzi doskonalenia procesów na kształtowanie relacji w łańcuchu dostaw. In: E. Gołembska, Z. Bentyn (Eds.), Logistyka międzynarodowa $w$ zmiennych warunkach gospodarki światowej (pp. 122-134). Poznań: Wydawnictwo UE.

48. Urbanowska-Sojkin, E. (2013). Ryzyko w wyborach strategicznych w przedsiębiorstwach. Warszawa: PWE.

49. Wilhelm, H., Schlömer, M., Maurer, I. (2015). How dynamic capabilities affect the effectiveness and efficiency of operating routines under high and low levels of environmental dynamism. British Journal of Management, 26(2), 327-345. doi: $10.1111 / 1467-8551.12085$. 
50. Witkowski, J. (2010). Zarzadzanie łańcuchem dostaw. Koncepcje. Procedury. Doświadczenia. Warszawa: PWE.

51. Vitasek, K. (2016). Strategic sourcing business models. Strategic Outsourcing: An International Journal, 9(2), 126-138. https://doi.org/10.1108/SO-02-2016-0003. 